\title{
Property and the Interests of Things: The Case of the Donative Trust
}

\author{
Johanna Jacques ${ }^{1}$ iD \\ Published online: 12 April 2019 \\ (c) The Author(s) 2019
}

\begin{abstract}
Within a liberal, 'law of things' understanding of property, the donative trust is seen as a species of gift. Control over trust property passes from the hands of settlors to beneficiaries, from owners to owners. Trust property, like all other property, is silent and passive, its fate determined by its owners. This article questions this understanding of the trust by showing how beneath the facade of ownership, the trust inverts the relation between owner and owned, person and thing. It analyses the relation that trustees, beneficiaries and settlors have to the trust property and argues that the role of each of these parties can be shown to consist in furthering the interests of the trust property rather than their own. It claims that this protects things from their owners at the same time as it ensures these owners' ongoing care towards the things they own. This raises questions about the trust's status within the institution of private property, justified as it is by the human autonomy it is said to enable.
\end{abstract}

Keywords Autonomy · Donative trust · Persons and things · Private property · Property theory $\cdot$ Trusts law

\section{Introduction}

According to the liberal understanding of private property, there is an 'equal right of each and every person to acquire and keep whatever is available to her or him for acquisition by lawful means' (Cotterrell 1987, p. 87). The idea is that people have an equal right to pursue their aims in life, from which follows a corresponding equal right to acquire the resources that will enable them to pursue these aims. This is a political conception of property; on the juridical side, this conception is associated with a certain form of the property relation, also called 'the law of things' (Smith 2012), which results from the function of property in facilitating individual autonomy. This function requires that property entails the right to control things in

Johanna Jacques

johanna.jacques@durham.ac.uk

1 Palatine Centre, Law School, Durham University, Stockton Road, Durham DH1 3LE, UK 
accordance with one's interests as well as the right to deny others the use of these things; in short, property must have an in rem aspect coupled with a residual claim (a sphere of unspecified uses), and it must have the right to exclude (Smith 2012, pp. 1709-1710). Property, on this account, even if it ultimately pertains between persons, involves a certain direct relation between persons and things.

One would be forgiven if one missed a fundamental premise of private property at work in this conjunction of ideas (henceforth referred to as the liberal conception of property). Despite the conventional use of the term 'property' to denote things themselves as well as the concept or institution of property, property is primarily about persons and their interests, things playing a merely secondary role. This is most obviously so for the liberal conception of private property, but even if one moves from individuals to collectivities and exchanges liberty with utility, this particular aspect of the property relation remains unchanged. It is not only that things on their own, unattached to persons, are not property; ${ }^{1}$ the whole purpose of property is to provide and justify control by persons over things. To suggest, as this article will do, that things which are subject to a trust arrangement, and therefore are private property, have a measure of independence, and that they furthermore control the persons supposed to be their owners, is therefore deeply counterintuitive. As James Penner writes with curious foresight, 'it would indeed be a funny turn of events if the norms serving our interest in property in essence gave the things a person owned a power over him' (Penner 1997, p. 79).

In light of the pervasiveness of the liberal conception of property, it is unsurprising that an express beneficiary trust is often seen as involving the transfer of property interests between two owners. After all, when property that is destined for a trust leaves the hands of the settlor, it cannot be released into a state where it would exist on its own. It must attach to a new person who will control it in turn; hence, an owner must be found. This article seeks to question this understanding of the trust by showing that none of the potential candidates for ownership in a trust arrangement fits into the role of the liberal private property owner and that both the trustee and the beneficiary stand in the service of the trust property. The claim is that the trust enables things to exercise a measure of legal agency by inverting, underneath the facade of ownership, the relation between owner and owned in such a way as to give things control over the people owning them.

It is, however, difficult to make generally-applicable observations about an arrangement as varied in its forms and purposes as the trust. For this reason, the trust that will serve as the object of analysis here is the kind of private donative trust that is commonly regarded as an alternative to an outright gift, that is, a trust where property that might otherwise be passed directly to children and other family members is instead settled on them as the beneficiaries of the trust. While this limitation may be thought to also limit the general applicability of the theory advanced here,

\footnotetext{
1 The only way in which the concept of property can take account of such things is as common property, whether this is thought to be ownership by everyone or no-one. If things are found to be ownerless yet are not in the commons, they either become property of the Crown or, like body parts, are not subject to property rights at all.
} 
it serves to avoid the rejoinders so easily enumerated when confronted by any proposed theory of the trust, namely that there are invariably aspects found in different forms of the trust that disprove the validity of the proposed theory, and that in any case settlors have their idiosyncratic reasons for establishing a trust. These rejoinders could easily lead to the conclusion that the most that can be said about the trust is that it is flexible in practice, a fact which may be justified on the basis of moral, commercial or practical, but rarely on property-theoretical grounds.

In contrast, the account of the trust presented here expressly aims at making a theoretical statement about the trust as a property arrangement. While conscious of the fact that this involves certain claims that in practice may not be true in every instance of the kind of trust discussed here, it is hoped that the evidence presented will be sufficient to show that it is possible-indeed plausible-to think about the trust in different terms. The ultimate aim is to introduce a way of thinking about the trust that represents a shift in current parameters and leads to the questioning of the trust's role in the theory and institution of private property.

One may counter at this point that the 'law of things' conception of property that regards individuals as having dominion over discrete things is no longer current and should be discarded (Grey 1980, p. 73). In this respect, one might point to the view of property as a bundle of rights not involving a particular relation between persons and things (Hohfeld 1917; Honore 1961), to the fragmentation, limitation and contingency that is true of common law property rights in any case (Matthews 2006, p. 290) or to the effects on the concept of property of the separation of control from ownership in the corporation (Berle and Means 1991). Accordingly, trusts law scholars have variously argued that trusts law belongs in the law of obligations rather than the law of property (Langbein 1995), that equitable property rights are rights against rights rather than rights against persons or things (Smith 2008; McFarlane and Stevens 2010), that the trust is merely one example of a property sharing arrangement (Worthington 2018) or-a mainly North American development-that trusts law is organisational law (Sitkoff 2004) and the trust effectively an entity (Hansmann and Mattei 1998).

In contrast to these approaches, this article will adopt an explicitly liberal, 'law of things' understanding of the trust based on Penner's understanding of property in The Idea of Property in Law. Support for such an approach can be found in trusts theory and doctrine to date, which employs a number of notions that make sense of the trust in a liberal private property framework. Foremost amongst these is the notion that the trust is a species of gift (Langbein 1995, p. 632; T Choithram International SA v. Pagarani [2001], per Lord Browne-Wilkinson at [11]).

\section{The Trust Within Liberal Property Theory}

The liberal conception of the donative trust as a species of gift disregards the inherent negativity of the trust form, that is, its being not an outright gift. While the trust has always openly been acknowledged as a means of withholding property from certain parties, whether from lords and creditors in the 14th century (Maitland 1913, pp. 226-227) or from tax authorities today, these are generally thought to be third 
parties rather than the beneficiaries themselves. The latter are almost universally regarded as the persons to whom the settlor seeks to provide benefits as a matter of central motivation, even when the trust takes the form of a protective or spendthrift trust (Langbein 2010). Indeed, the restrictions imposed on beneficiaries often get lost when the beneficiaries are described as the true owners of the trust property. ${ }^{2}$ The assumption is that the restrictions imposed on the beneficiaries, such as the inability to access the capital of a trust fund, are referable to the protection of the beneficiaries' property from third parties, not to the intentional withholding of property from the beneficiaries themselves.

This view of the beneficiaries as the substantive owners of the trust property not only opens the door to the categorisation of the trust as a species of gift; it also invokes the general view of the trust as a means of property ownership that is only restricted in order to protect the owners and their property from the claims of third parties. The trust then becomes a hyper-private version of private property which, in the attempt to hide its own existence from the state and other interested third parties, denies its liberal core, that is, the owners' control over the property owned.

Rather than adopting this view, which conveniently fits the trust into the liberal property framework, what if one took the 'wedge' ${ }^{3}$ driven between the trust property and the beneficiaries seriously? Instead of seeing this wedge as a necessary evil to protect the beneficiaries' ownership of the trust property from third parties, one could see it as the means to protect the property itself from the beneficiaries, and do so without recourse to the eternal rejoinder that this protection will ultimately benefit these or future beneficiaries, which would align the trust once again with the liberal conception of property.

The new view involves two changes in the way the trust is commonly conceived: the first is a replacement of the settlor's intention to make a gift with an intention to safeguard the property from any potential fragmentation, dissipation or destruction at the hands of beneficiaries. Such a replacement transforms the trust into an anti-liberal arrangement, as the fragmentation, dissipation or destruction that the settlor seeks to avoid is not that which could result as a secondary consequence of liberal private property ownership (such as the bankruptcy of the beneficiaries or taxes levied upon them) but that which is the intended consequence of liberal private property ownership, namely the dissipation caused by the beneficiaries' use of the property to further their own interests. The trust thus becomes an arrangement that explicitly opposes the use of property by its owners in the pursuit of their interests.

The second is a replacement of the interests of the beneficiaries under a trust with the interests - to be clear, these are not inherent interests but interests specified by

\footnotetext{
2 As, for example, in Scott (1917), Lau (2011, p. 164), Penner (2014). Maitland (1911, p. 349, 1913, pp. 23-24) writes that the beneficiaries, though not owners strictly speaking, for most people are as good as.

3 The term 'wedge' has been borrowed from Maitland (1911, p. 355), who uses it when recounting how the separation of legal from beneficial interests in marriage settlements eventually lead to women being able to own their own property: 'The wedge was in, and it could be driven home. It was a long process; but one successful experiment followed another.' While Maitland is here referring to a 'crack' in the property regime as a whole, the metaphor could equally be applied to the separation of legal and beneficial interests under a trust.
} 
the settlor when establishing the trust-of the trust property. This replacement transforms the trust from a property arrangement primarily concerned with ownership and thus ultimately with (the interests of) people, to a property arrangement primarily concerned with (the interests of) things.

Both of these replacements will be further elaborated below. For now, it may be helpful to address some of the difficulties that such an account of the trust faces when approached from the perspective of liberal property theory. To begin with, the notion that inanimate things can have interests of their own is not easily reconciled with such theory. Even though all that is suggested here is that things can be given interests by the settlor in the form of aims or purposes that the settlor attaches to the property when establishing the trust, this goes against the firmly held view that only persons can have interests, and that any value underlying those interests "can only be a value if it (positively) contributes to the well-being of people, and is therefore in their interest to realize' (Penner 1997, p. 10). Liberal property theory regards the property relation as one that holds between autonomous, acting persons and interestabsent, passive things, and the only way in which things can be thought of in terms of their interests is by subsuming them under a structure that has legal personality, such as the company, or by awarding them legal personality themselves. ${ }^{4}$ However, these measures merely entail the pulling of the 'thing' onto the 'person' side of the person-thing distinction, leaving the distinction itself intact. In contrast, the claim made here is that trust property is afforded a measure of legal agency without involving any fiction of personality, and thus as thing.

One might also counter that even if one accepted that things can have interests in law, much of the property currently held on trust is in the form of a fund rather than of discrete things. One therefore cannot, so it might be argued, maintain that interests attach to trust property, as each component of a fund may be replaced for another by the trustee without such interests thereby transferring to the transferee. However, as Penner (2009) convincingly argues, Equity treats all trust property as akin to a fund, in that the rights of the beneficiary are transferred to the trust property's exchange value as long as that property is moved out of the trust in accordance with the trustee's powers. 'An interest in a fund', Penner (2009, p. 315) writes,

is an interest not only in the assets in it at the moment but in those assets to the extent they become realized via exchange.... There is, in consequence, no difficulty whatsoever in applying all the normal rules which compose the law's treatment of property [to a fund].

It is therefore not implausible to claim that, if trust structures can be used to bestow interests upon things, these interests are as capable of attaching to a fund (things or their exchange value) as they are of attaching to discrete things, be they real (such as an heir loom) or legal (such as a chose in action). This is particularly easy to envisage because these interests are bestowed upon the property rather than independently generated by it, and therefore do not require an origin locatable in the particular characteristics of a thing.

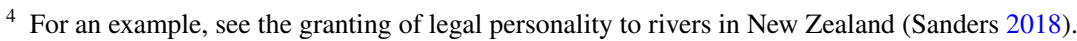


Indeed, the trust form may enable the creation of things in the first place by defining the properties or contents of a fund. Delineated things are a necessary component of the liberal property framework, as without them neither open-ended use nor exclusion could take place. If the settlor wishes to make either a collection of specific things or the overall value of unspecific things into a 'thing' for the purposes of property, the trust provides him with the means of doing so. Cotterrell (1987, p. 85) thus sees as one of the advantages of the trust that 'it makes possible the creation of enduring objects of property ("things", clusters of value) in the form of funds', while Smith (2012, p. 1722, n. 123) hypothesises that 'beneficial interests in trust and other equitable property rights can be captured as an iterative use of the recursive process of making a modular thing (reification)'.

Also related to the problem of accounting for the interests of things is that of accounting for the priority given to these interests over the interests of persons, that is, the problem of the legal standing of things. Under the liberal conception of property, an asymmetry of control between persons and things is seen as the hallmark of the property relation, which 'dictates the absolute control of the owner over the thing ... and the corresponding absence of any "control" of the thing over the owner' (Penner 1997, p. 121). This asymmetry follows directly from the assumption that property law must work in people's interests, not in the interests of things. Thus, the sole purpose of law, including property law and therefore also the legal institution of property, is regarded as the exclusive furthering of our interests ('we' meaning persons subject to the law), a view whose correctness Penner (1997, p. 12) describes as 'obvious'. ${ }^{6}$ While the liberal view does recognise certain limits to what an owner can do with the things he owns, these are seen as social limits rather than as limits arising from the property itself. This also holds true for theories like those of Shoked (2014, p. 444), which argue that 'property contains a general, persistent, ancient, and expanding affirmative duty to maintain an owned asset', but which describe this duty in terms that only ever reflect the interests of persons, not of things (also see Peñalver 2010).

Even if one did not adopt the liberal view of property as based on a right to further one's individual interests through the use of things, one might still be left with property as an institution that works exclusively for human interests. Perhaps this is most obviously so for communitarian or 'social obligation' theories of property that regard property rights as based on a plurality of values, including the common good (Alexander 2011; also see Alexander et al. 2009). However, other perspectives on property, some critical of the liberal view, also implicitly adopt this understanding. Kelsen (1967, para. 29(b), p. 131), for example, sees the fact that property is referred to as dominion by a person over a thing as ideological; namely, to hide 'the economically decisive function' of the property relation as an inter-personal relation whereby an owner may exclude everyone else from his property. Cotterrell similarly describes the function of property as establishing relations of private power through the ownership of things, and refers the inability of property law to

\footnotetext{
5 Cotterrell's treatment of funds diverges, however, from Penner's in other respects.

6 This claim is widely shared. See, for example, Smith (2012, pp. 1693 and 1704).
} 
recognise 'disembodied' property, that is, things without a person who owns them, to the frustration of this function that would logically follow. He gives the example of private purpose trusts, which are commonly seen to 'orphan' assets, writing that 'it is thus unsurprising that courts have tended to see private purpose trusts in general as fulfilling no purpose deserving of the protection of law' (Cotterrell, 1987, p. 88). Even Pierre Lepaulle, whose analysis of the trust as 'a patrimonium [that] can exist by itself ... without being owned by anyone' (Lepaulle 1933, p. 21) resonates with many of the arguments made here, sees the trust as a form of social property whereby protecting things from individual interests benefits society as a whole (Lepaulle 1928).

Hence, whether as a matter of obvious legal rationality or of uncovering the power structures underlying the liberal ideology of property, there seems to be a consensus that the legal theorist approaching the institution of property must view its constructs through the prism of persons' interests. If they are not so viewed, then at least for Penner (1997, pp. 12-13) the theorist's categories are defective and, if used as a basis for decisions, will lead to confusion and injustice. It might therefore not only be incorrect to say that things have interests that the law recognises but also normatively wrong to do so, both in the sense that law has no reason to protect such interests and that advocating such protection may lead to substantive injustice by shifting power structures in unforeseeable ways, whether these are power structures between persons or between persons and things.

There is little that can be said to appease such concerns without thereby re-establishing the priority position of persons over things in property theory, a position which this article aims to dislodge. However, it is worth being precise about the intended outcome: the new view of the trust proposed here will do both more and less than other accounts of the agency of things. By arguing that things governed by a trust have legally enshrined interests of their own, it will do more than point to the way in which things co-determine the legal relations constructed to govern their use in the way that this has been shown, for example, in relation to physical models of inventions and patent law (Pottage 2011, p. 632). Such arguments typically leave the proposition intact that the law of property is there to further 'our' interests. ${ }^{7}$ On the other hand, by showing that things can be given interests that are legally recognised, the new view will do less than the claim that things are reflective agents in the way humans are or that their ability to bear interests otherwise reflects on their intrinsic value. In other words, there is no intention here of, in Martin Holbraad's terms, 'widening the circle of the human' (Holbraad 2011). Indeed, it is not necessary to claim that things have intrinsic rather than merely 'conditional' or 'relative' (Kant 2012 , p. 40 [4:428]) value if it is accepted that this value and its associated interests can, once conferred, detach from its human originator and attach to things as theirs. Thus, all that is claimed here is that the trust effects the erasure of the legal divide between persons and things, not the erasure of a factual difference. ${ }^{8}$ In short, the

\footnotetext{
7 As argued, for example, by Rose (1994, p. 269) and by Lametti (2003).

8 As Latour (2005, p. 76, n. 88) writes: 'Human and objects are clearly distinct.... But a difference is not a divide.'.
} 
focus is neither on the moral standing of things nor on their ontology, but on the way in which property law treats things in the case of the donative trust.

\section{The Trust is Not a Species of Gift}

An express trust is usually conceived of as a transactional device, 'a structured transfer of property from the settlor to the beneficiaries' (Penner 2002, p. 261), 'a gift that will take effect over a period of time' (Lawson and Rudden 2002, p. 55). In relation to the donative trust, the gift analysis serves to justify settlors' rights to establish a trust over their property (the right to make gifts being generally acknowledged to form part of an owner's rights) as well as the beneficiaries' rights to hold interests under a trust. And yet, there are good reasons for the view that the trust is not a species of gift.

To begin with, to see the trust as a species of gift entails looking positively at the interests of beneficiaries and describing them as 'essentially future, legal, interests' (Penner 2014, p. 485), that is, as the proceeds from their equitable interests that are distributed to the beneficiaries in legal form, whether during the trust's duration or once it comes to an end. This point of view regards the fragmentation of benefits over a number of beneficiaries as the 'fragmentation of ownership over time' (Garton 2015, p. 73). What is implied here is that by taking all the benefits togetherbenefits which are known to reach beneficiaries in the form of legal proceeds-and ignoring the intervening period in which beneficiaries merely hold equitable interests, one ends up with a transfer of property from one hand to another. What the trust enables is simply 'to carve up the common law interests in property amongst the beneficiaries' (Penner 2014, p. 485), the implication being that the carved-up pieces amount to a whole.

Two issues arise in this respect. The first relates to the postponement of the benefit. While all gifts may have an 'element of futurity' (Penner 1997, p. 99), that is, a period of time that intervenes between the making of a gift and the furthering of the donor's interests through the donee's use of the gift, the futurity in question here is of another kind, as it postpones the point at which the property reaches the hands of the donee in the first place. This postponement suggests an alternative view of the interests that beneficiaries receive, namely, to look at them negatively as interests that now essentially fall short of the absolute control that would have been afforded to them had the transfer been made as an outright gift. This difference becomes significant when one considers why liberal property theory regards gift-giving as one of the rights of property owners in the first place.

A gift is a process by which property gratuitously passes from one person to another. Under liberal property theory, for such a transfer to be justifiably upheld at law, it must have a reason, and this reason must furthermore be rational (Nozick 1974, p. 159). According to Penner (who follows the work of Joseph Raz in this

\footnotetext{
9 Hansmann and Mattei (1998) make this understanding even more explicit by calling the settlor 'transferor' and the beneficiary 'recipient' (the trustee is 'manager').
} 
respect), this reason must also relate to the donor's interests rather than his desires. Penner (1997, p. 10) distinguishes interests from desires by saying that only the former are based on a 'critical understanding of values, i.e. of those things which are truly of worth and those which are not'. The particular interest that underpins the institution of property, Penner claims, is our interest in autonomy. This is because 'the freedom to determine the use of things is an interest of ours in part because of the freedom it provides to shape our lives' (Penner 1997, p. 49). According to Penner (1997, pp. 88-90), gifts satisfy this criterion of self-interest because they transfer property in such a way as to further the donor's interests through their use by the donee in accordance with his (the donee's) interests. They can therefore be seen as an instance of the donor's use even if he has no further control over the property. Where the donee does not derive a benefit from the gift, the interests of the donor are equally frustrated.

This view of the interests grounding the legal ability to make a gift entails considerable uncertainty for the donor, who cannot be sure that his interests will ultimately be furthered. However, despite this uncertainty, Penner (1997, p. 90) warns against restricting the use of the gift by the recipient. 'There is simply no good reason ... for post-transfer legal restrictions on use', he writes, 'for they would ... defeat the purpose of the transfer contemplated'. This purpose, he explains, is not just the making available of resources and their associated benefits to the donee but also the decision-making capacity that comes with the possibility of using these resources in the first place - that is, the autonomy that a property relation enables. This autonomy can be seen as a function of the autonomy of the donor, as furthering his interests by furthering the autonomy of the donee. Penner (1997, pp. 89-90) demonstrates how this works using the example of gifts given to one's children:

I regard it as deeply in my interests that they [my children] grow up to be capable, autonomous individuals who have a reasonable facility for managing their own lives. There is no way that I am going to contribute to this development by devising ever more sophisticated ways of manipulating the way they 'choose' to act. They must actually choose ... [if they are to] understand what making significant choices is all about.

This makes it difficult to regard the trust as a species of gift, as it intentionally restricts beneficiaries' control over the property as a whole, not permitting them to use it for their own purposes. As Garton (2015, p. 296) writes, 'placing property into trust to be invested and managed by trustees obviously reduces the autonomy of beneficiaries as compared with absolute ownership'.

The second issue that arises in relation to the view of the trust as merely effecting a fragmentation of ownership concerns the distribution of benefits under a trust. One could argue that the restriction of, say, one beneficiary to income and another to capital simply signals the positive intent to benefit more than one person (the restriction of the interests of one being referable to the intent to also benefit another). However, a more plausible view is to see this distribution of benefits as a means to protect the trust property from ownership. Garton (2015, p. 296), for example, explains the motivation behind reducing beneficiaries' autonomy as follows: 'Capital is thereby protected from destruction at the hands of present beneficiaries 
since the only property interest that the latter are likely to possess during the trust's existence is an entitlement to income.' Formally, the distribution of benefits under a trust thus prevents the property from falling into the hands of a single owner. Substantively, it ensures a certain handling of the trust property that the settlor deems appropriate to its (the property's) interests (a house: to be lived in and be kept in good repair; a fund: to be protected from dissemination and grow in value) and provides the incentive for beneficiaries to enforce the settlor's instructions. Thus, the distribution of benefits creates an interest in the short-term production of income by the trust property, while the promise of absolute ownership creates an interest in the integrity and growth of the property over time. The courts may say that keeping a balance between these interests is necessary to protect the beneficiaries' entitlements (Re Tempest [1865-66]), but it is ultimately the property which benefits. The beneficiaries' interests thus play the role of generating an interest on the part of the beneficiaries in the property's survival and growth over time. A legal space is created in which property can exist without being endangered by its owners' needs for consumption, but nevertheless benefits from their care.

\section{The Trust Inverts the Ownership Relation}

\section{The Trustee}

There is little doubt that the trustee's relation to the things that make up the trust property is one in which ownership in a substantive sense is withheld. Thus, a trustee cannot use the things he holds on trust to further his own interests or to satisfy the demands of his creditors (Rudden 1994, p. 82), and the asset protection function associated with the trustee's lack of equitable title in the trust property is widely acknowledged. ${ }^{10}$ Lawson and Rudden $(2002$, p. 86) even go as far as stating that the term 'legal owners' for trustees is 'both inaccurate and misleading', as trustees may hold equitable as well as legal interests on trust, and '.. are not really owners because they cannot treat the property as their own'.

Accordingly, it matters little for the fate of the property who the trustee is and what his interests are (Penner 2002, p. 261), the office of the trustee being 'in effect (though not formally) a separate entity from the trustee personally' (Sitkoff 2004, p. 641 , footnote omitted). Rather than as a person in control of a thing, a trustee should therefore be conceptualised as an impersonal agent of the trust property. Indeed, the lack of self-interest on the part of the trustee is so pronounced that the office of trusteeship can be seen as being emptied out of personhood altogether, particularly given that it may lie vacant for a period of time without thereby affecting the validity of the trust (Nolan 2015, p. 701). Penner (1997, p. 135) thus describes the trustee as 'the personification of the trust agreement' and 'a human instrument'.

${ }^{10}$ Indeed, Hansmann and Mattei (1998, p. 466) regard this as the main contribution of the trust. 


\section{The Beneficiary}

While it goes without saying that beneficiaries do not have control over the trust property as a whole, one might argue that the rules that allow beneficiaries to vary the trust or bring it to an end effectively constitute them as the property's owners. Cotterrell (1987, p. 86), for example, finds his own view that the trust form merely serves to hide the status of beneficiaries as property owners confirmed by rules such as the rule in Saunders v. Vautier, that is, rules which shift the balance of rights from trustees to beneficiaries. Although Cotterrell recognises that the trust extends and ultimately overcomes the private property form of person-thing, and although he also recognises that 'in this way the trust greatly facilitates the concentration and preservation of capital' (Cotterrell 1987, p. 85), he sees this concentration and preservation as accruing power to the 'real' owners, namely the beneficiaries. His critical analysis of the trust thus serves to reinforce the view of the trust as a means of private property ownership.

This argument is not easily refuted. Indeed, it is with the rule in Saunders $v$. Vautier (and its derivative rules on trust variation) that the question for whose interests the trust really works comes to a head. While under normal circumstances, beneficiaries can demand 'to have the trust duly administered in accordance with the provisions of the trust instrument, if any, and the general law' (Target Holdings Ltd v. Redferns [1996], per Lord Browne-Wilkinson at [434]), but cannot demand to have the trust administered according to their own ideas and interests, the rule in Saunders v. Vautier enables beneficiaries to turn their beneficial interests into absolute ones so that they may then deal with the property as they wish. Equally, in a variation of trust it is the beneficiaries' interests that provide the main criterion by reference to which a court may approve a variation (Variation of Trusts Act 1958, s. 1), and while in the American context it is sometimes said that the provisions allowing for the variation of trusts 'are designed to advance the settlors' probable intent' (Sitkoff 2004, p. 661, footnote omitted), English courts have expressly gone against such intent in favour of the beneficiaries (see, for example, Goulding v. James [1997]). Unsurprisingly, therefore, the process that allows for the termination of a trust by its adult beneficiaries under the rule in Saunders $v$. Vautier (and by extension for the variation of a trust), has been said to resolve the assumed conflict of interests between settlors and beneficiaries in favour of the latter (Harris 1975, p. 5).

There are, however, arguments one can make for the proposition that the rule in Saunders.v Vautier does not entail the effective ownership of the trust property by the beneficiaries. In relation to the rule itself, it is arguable that the power that it confers on beneficiaries should be regarded as an aspect of the termination of the trust-because involving its collapse-rather than its operation, and that it therefore has little bearing on the relations between the parties and the property during the time that the trust is operative. Getzler (2009, p. 369) writes that this is not necessarily true, as

beneficiaries could use this power [to collapse the trust] to shape the way in which trustees [wield] their discretions, ... to remove and replace trustees, 
or to apply to court for reformation of the trust terms, stopping short of collapsing the extant trust.'

However, Getzler also points out that the rule in Saunders v. Vautier could easily be defeated by scattering interests amongst multiple beneficiaries who are then unlikely to be able to act unanimously in bringing the trust to an end, allowing family pressures to be applied in the meantime in favour of resettlement to the next generation and thus explicitly against the immediate interests of the beneficiaries. The rule, he writes, thus serves to avoid the prohibition of perpetually running trusts through its potential application, while also serving to avoid the taking of the property absolutely by beneficiaries through its actual suspension, a fact which he compares to 'the long practice of dynastic families using strict settlement to induce each inheriting generation to resettle the family estate to the next round of grandchildren' (Getzler 2009, p. 372). ${ }^{11}$ He concludes that

the rich in Britain today ... remain wedded to the rule in Saunders not because they want beneficiaries to have power to break trusts, but because of the great assistance the rule affords to asset management and tax minimization (Getzler 2009, p. 386).

Indeed, financial benefits that directly accrue to the trust property often take centre stage in variations of trusts, although this is usually hidden by the court's references to the beneficiaries' best interests. Thus, although non-financial interests sometimes play a part, the interests that are most often considered by a court deciding on a proposed variation are not in fact the beneficiaries' actual but their financial interests (Tucker et al. 2015, para. 45-091, p. 2235), a term which has been known to translate not into their actual financial interests but into the interests they can be said to have in the protection and growth of the trust property over time, most often in the face of a threatened reduction of the property through taxation (Watt 2018, p. 316). In practice, therefore, the interests of the beneficiaries are taken to be their interests in the growth of the trust property. Trusts law is a law of things, not persons; it is the property itself that the court looks to and for which it must take the right decision.

For liberal property theory that regards things as always already in the hands of absolute owners of one kind or another, the shift in focus from the person to the thing here makes little difference, as even when the owner has no actual interest in the growth of the property, that growth can accrue only to the owner. However, when one begins to consider the trust as a mechanism that drives a wedge between an owner and his property (distinct from absolute ownership, which separates the person-property construct from the rest of the world), and that bestows onto things interests of their own, this shift begins to matter. On this view, the divergence

\footnotetext{
11 As Spring (1964, p. 210) explains, strict settlements intentionally lacked provisions for the male heir's upkeep before he succeeded in title, rendering him dependent on the good-will of his father, himself a life tenant with limited rights over the estate. The father would then use his position to negotiate the re-settlement of the estate on terms similar to the existing terms in return for adequate provision to the heir in the years prior to his coming of age. This process ensured that the property would never go out of settlement.
} 
between the real interests that beneficiaries have in the property as its 'owners' and those that are taken to be their interests by the court reveals the trust as a mechanism that protects things from people under the guise of a traditional property relation. If the trust is an arrangement that 'protects accumulated private wealth', ${ }^{12}$ it no longer protects the wealth of someone, but wealth as such.

\section{The Trustee and the Beneficiary, Taken Together}

A different way in which the restrictions that a trust imposes are sometimes disregarded in order to fit the trust into the liberal conception of private property is by taking the trustee and the beneficiary as collectively constituting an absolute owner (see, for example, Jaffey 2015, p. 387). This is problematic, not least because, as Grey (1980, p. 70) sets out, certain rights disappear in the split of legal from equitable title when property is placed on trust.

The rights that Grey sees disappearing on the establishment of a trust, such as the right to leave land idle, are important rights in the liberal theory of property. They are the rights that Penner (1997, pp. 78-79) links to the autonomy interest that lies in 'not dealing' with property one owns, an interest from which, in his view, follows the right to abandon property. In Penner's theory of property, this right to abandon plays a dual role. Firstly, the right-Penner here does not mean the actual legal right, the existence of which would depend on other people's rights and expectations and is in practice at the very least doubtful-is indicative of a property relation: 'If a person is unable to free himself of a thing, then to that extent he is controlled by his relationship to the thing, if not by the thing itself. Such control is antithetical to the idea of property' (Penner 1997, p. 78).

Secondly, the right to abandon functions as a test for whether something is capable of being owned in the first place. Only objects that are 'silent' can be owned: 'A thing has nothing to say about the relationships it has' (Penner 1997, p. 81). Silent objects make no claims on their owners, which is important because only then can the asymmetrical relation of control that is the property relation be established:

A fundamental aspect of the property relation between an individual and a thing is its asymmetry. The individual is not on a par with the thing. The individual has control of, or over, the thing, as far as an individual is capable, and not the other way round. (Penner 1997, p. 78)

In this respect, the right to abandon is a better indication of the asymmetry of control involved in liberal property ownership than the right to destroy. ${ }^{13}$ While destruction may silence things, the possibility of abandonment means that things are

\footnotetext{
12 Such as when Chesterman (1984, p. 167) writes that in the last resort, the family trust and the law relating to it, with all their powerful moral and ideological overtones, combine to protect accumulated private wealth'.

13 And it is therefore also a better indication of ownership of trust property than the right to destroy, the absence of which in relation to trustees is commonly remarked upon (see for example, Rudden 1994, p. $82)$.
} 
already silent, that they have nothing to say and may thus be taken up or let go of at will and without protest on their part. It is this silence which, according to Rose (1994, pp. 271-272) accompanies the property relation, expressed through 'the language of domination, that ultimate form of objectification.'

The pertinent questions are therefore whether trust property is of the silent type without a subjective will of its own (and is therefore the object of ownership) and whether the trustee and beneficiary together can abandon it as they wish (and are therefore in a position of absolute control over it). In this respect, both trustee and beneficiary are in a curious position. While each, given certain conditions, may be able to relinquish their office (trustee) or interests (beneficiary), neither of them (nor both of them together) can unilaterally effect a change in the ownership status of the trust property without first dissolving the trust, this change in ownership status being the very change that Penner aims at with the right to abandon. ${ }^{14}$

Thus, trustees may refuse to take up their office or may step down from it, but they are under various duties in respect of the trust property until they do so, duties that partly stem from the general law of trusts, partly from the trust instrument attached to the property. ${ }^{15}$ Once in their office, they cannot effectively abandon the trust property through neglect, as they are under a duty to be actively involved in trust matters. If they refuse to act as trustees, the trust property, 'either pursuant to machinery in the terms of the trust, or by a court order' (Smith 2008, p. 384), finds itself substitute trustees. This replacement is driven by the property and its terms, not by any new trustee, and it is thus the diametrically opposite process to that of a new owner taking up abandoned property. In other words, it is the trust property itself, not its legal owner, who determines the property's ownership status.

A similar argument about the ability to abandon can be made in respect of beneficiaries and the beneficial interests they hold. While beneficiaries are able to divest themselves of their interests, including by abandoning or renouncing the interests they hold (Quaintance v. Tandan [2012]), ${ }^{16}$ this does not effect a change in status of the trust property as a whole, as it is not possible, at least under English law, for trust property not to have beneficiaries. ${ }^{17}$ Because of the law's liberal self-understanding, things circulating in society must be 'held' by someone or by all: 'The equitable, or beneficial interest, cannot remain in the air' (Vandervell v. Inland Revenue Commissioners [1967], per Lord Wilberforce at [329]). The trust property, through the law of trusts in which it has legal agency, will therefore find itself beneficiaries as it finds

\footnotetext{
14 Dorfman (2010, p. 18) also makes a claim about the relation of ownership to the ability to effect a normative change, although for him the change that an owner must be able to make (in order to be an owner rather than a mere possessor) is in the normative status of other persons vis-à-vis the object, not in the normative status of the object itself vis-à-vis the world in general, as is claimed here.

15 The terms of the trust are best regarded as attached to the property itself rather than as constituting an agreement between settlor and trustee (Penner 1997, p. 262). Langbein (2010, p. 382, emphasis added) equally talks about the settlor as 'having chosen to impress the property with fiduciary obligation'.

${ }^{16}$ I am grateful to Nick Piska for pointing me to this case.

17 For the effects that this rule may have on the increasing use of 'massively discretionary trusts', see Smith (2017).
} 
itself trustees, and sometimes (as, for example, in the Vandervell litigation) it will do so against their will.

This means that beneficiaries are even less able to abandon trust property than trustees, who at least cannot be forced to take up the role. However, rather than seeing this attachment of persons to things as an indication of ownership, it should be seen as the opposite, namely, as an indication of the fact that neither trustee nor beneficiary are in the position of a traditional property owner. Lepaulle (1928, p. 55) points to this fact when he describes the trust as an arrangement in which a thing is 'appropriated' (in the sense of 'dedicated') to further a certain aim, with the rights and duties of trustees (as well as beneficiaries) being determined solely by the need to achieve this aim. Ignoring for a moment the fact that for Lepaulle, this aim is a social one rather than an aim that is related to the interests of the property itself, this statement is useful for realising that trust property is from the beginning not a 'silent' thing that is taken up and made to 'speak' as part of its being owned by one or more persons, but is already speaking with an independent voice when trustees and beneficiaries first make its acquaintance-a voice which used to belong to the settlor but which has been transferred to the trust property in the form of the trust instrument. The abandonment by the trustees and beneficiaries of their roles therefore cannot return the property to a silent state.

\section{The Settlor}

Finally, an alternative explanation to ownership by trustees or beneficiaries which informs much doctrinal discussion of trusts law is that the trust is a mechanism by which the settlor imposes his will on the use of property even after he has ceased to control it directly, determining the property's fate with 'the dead hand of the past' (Atiyah 1979, p. 88). For example, when variations of trust are portrayed as conflicts of interests between the two wills of settlor and beneficiary vying for control over the property (Re Chapman's Settlement Trusts (No. 2) [1959], per Vaisey J at [375]), the settlor emerges as a candidate for ownership equal to the beneficiary.

It is clear that a conflict of interests would preclude viewing the trust as a gift, as in a gift (at least according to Penner's version of it) the interests of donor and recipient are aligned. From this perspective, seeing the settlor as a continuing owner of the trust property opposed to the interests of the beneficiaries is a step in the right direction. However, this explanation of the trust employs another fiction, namely that the settlor somehow retains control over property even after he has relinquished such control by settling the property on trust, something which, at least under English law, is not the case. ${ }^{18}$

While the settlor's intentions in setting up the trust are sometimes considered by the courts when making decisions about trusts, there is no suggestion that these

\footnotetext{
18 See Re Astor's S.T. [1952], per Roxburgh J at [542] and Bradshaw v. University College of Wales [1988], per Hoffmann J at [194]. Also see Goulding v. James [1997]. Where a settlor retains a power of revocation he may amend the trust or bring it to an end, but this does not affect the day-to-day operation of the trust, in which trustees and courts must look to the trust instrument for their instructions.
} 
are other than historical intentions, frozen at the time at which the trust was established rather than being ongoing and potentially changing. Furthermore, the settlor's intentions rarely concern his own interests in dealing with the property. Rather than attempting to control the use of the trust property to derive a benefit for himself (which could more easily be achieved by retaining the property in the first place), the settlor attempts to dissociate the trust property from the interests of the beneficiaries by settling it on trust. This he does by effecting a break in the relation between the beneficiaries and the trust property, which, if it had been a relation of absolute ownership, would have rendered the trust property a merely passive means in the hands of the beneficiaries. The ensuing fragmentation and withholding of rights from the beneficiaries has the effect of taking the property out of the market, or if the trustees have the power to sell, of preserving its value. What the beneficiaries are unable to do is to invest it for their interests or consume its exchange value (Matthews 2006, p. 277). Insofar as the ongoing interests that are considered by the courts are concerned, these are the interests of the property itself, as reflected by the terms of the trust. This means that if the settlor can be said to control the trust property at all, it is through the terms he attaches to the property. A more accurate way of looking at the trust would therefore be to say that the settlor equips the property with interests that henceforth have to be upheld-and upheld as the property's interests, not those of the settlor. If there is a conflict of interests, it is between the beneficiaries seeking to assert themselves as the property's owners in order to use the property for their own interests and the property seeking, through the legal means available to it, to further its (the property's) interests.

But why designate new owners in the form of beneficiaries at all, risking that they may find a way of using the property for their own interests? Two reasons come to mind. The first is that the property must be formally owned if it is not to be available for general appropriation, an even more uncertain fate. While the settlor could settle the property on a charitable trust, this would elevate the charitable purpose above the interests of the property. The only way in which the settlor can ensure that his property persists over time is to place it in what appears to be a relation of ownership between persons and things, but break this relation so that these owners cannot make use of it to further their own interests. The second is that the property needs people who can be trusted to look after it. Breaking the ownership relation takes care of this trust aspect, but on its own it is not sufficient to ensure the owners' care, as unusable things (whether because they are broken or because of a lack of rights in them) become objects of indifference and neglect. ${ }^{19}$ This would not be in the interests of the property, so it is vital that one or more owners should be bound to the property as its agents. And how does one convince owners to act in the interests of the things they own? As already mentioned above, distributions to beneficiaries and the promise of future ownership generate an interest in the property on the part of beneficiaries. By giving the impression of ownership, these benefits also disguise the reversal of roles between persons and things under a donative trust.

${ }^{19}$ They become what Heidegger (1962, p. 104 [74], translator's footnote omitted) would describe as 'something which one would like to shove out of the way'. 


\section{Conclusion}

In the concluding paragraph of Property and Persuasion, Rose (1994, p. 297) remarks that

what you see in property is what you and others have talked yourselves into about those 'things'; and given some imagination, you may always talk yourselves into seeing something else-with all the effects on understanding and action that a new 'envisioning' may bring.

The preceding analysis has attempted to change the view of the donative trust through such a re-imagination from a species of gift to an arrangement that frees things from the control of their owners, enabling them to have and pursue interests of their own.

Is this still property? According to Matthews (2006, p. 289), 'property rights must be attributed to people. People can decide what to do with their property ... that is what the word means.' This would suggest that it is not possible to dissociate people and things and at the same time claim that the relation that remains still belongs to the category 'property'. However, if one were prepared to let go of the assumption that all law must necessarily serve human interests, and accepted that it is possible for humans to assign interests to things that are then operative in law on their own account, an arrangement in which people are recruited and rewarded for serving the interests of things would lose its implausibility as a property arrangement. On this account, property would no longer be that which is 'proper' only to persons. ${ }^{20}$

Indeed, Matthews (2006, p. 291) does consider the possibility of a change in the meaning of property, writing that 'law is a metaphysical construct and therefore can be modified and developed as we like'. Considering the rejection of the rule in Saunders $v$. Vautier and the adoption of the material purpose doctrine in the United States, as well as the more recent emergence of private purpose trusts in off-shore jurisdictions, such development seems long under way. In this respect, the view of the trust proposed here may help to shift the focus away from settlors and beneficiaries as owners and onto the property itself. By conceptualising things as capable of being given interests that then persist independently of either settlors or beneficiaries, it may be possible to move on from the interminably debated question whether it is the settlor's or the beneficiaries' interests that are, and ought to be, given precedence in trusts law. ${ }^{21}$

Whether to think of things as bearing interests is also desirable is, however, another question. The answer will depend on the value one places on human autonomy as it is furthered through the use of things. On the one hand, the view of the trust proposed here paints a picture of settlors primarily concerned with the accumulation and protection of wealth for its own sake rather than with its use by successive owners for their interests. The implication here is that autonomy no longer plays a leading role in the institution of property, with all the adverse consequences

\footnotetext{
${ }^{20}$ For the further development of this thought, see Jacques (2019).

21 See, for example, the exchange between Langbein $(2004,2010)$ and Cooper (2008).
} 
one may think this entails for the status of human beings in the relation between persons and things. On the other hand, the view of the trust proposed here may open the door to a law of property in which persons are no longer the only interest holders and in which the notion of ownership as a one-sided relation of control loses its hold. It may be time to question the certainty of the pronouncement that "no right of a thing against a person is conceivable' (Kant 1996, p. 126 [6:358]) and ask what it is that things which are legal actors can, and ought to, achieve.

Open Access This article is distributed under the terms of the Creative Commons Attribution 4.0 International License (http://creativecommons.org/licenses/by/4.0/), which permits unrestricted use, distribution, and reproduction in any medium, provided you give appropriate credit to the original author(s) and the source, provide a link to the Creative Commons license, and indicate if changes were made.

\section{References}

Alexander, Gregory S. 2011. Pluralism and property. Fordham Law Review 80: 1017-1052.

Alexander, Gregory S., Eduardo M. Peñalver, Joseph W. Singer, and Laura S. Underkuffler. 2009. A statement of progressive property. Cornell Law Review 94(4): 743-744.

Atiyah, Patrick S. 1979. The rise and fall of freedom of contract. Oxford: Clarendon.

Berle, Adolf A., and Gardiner C. Means. 1991. The modern corporation \& private property. New Brunswick, NJ: Transaction Publishers.

Chesterman, Michael R. 1984. Family settlements on trust: Landowners and the rising bourgeoisie. In Law, economy and society, 1750-1914: Essays in the history of English law, ed. G.R. Rubin and D. Sugarman. Abingdon, Oxon: Professional Books.

Cooper, Jeffrey A. 2008. Empty promises: Settlor's intent, the uniform trust code, and the future of trust investment law. Boston University Law Review 88: 1165-1216.

Cotterrell, Roger. 1987. Power, property and the law of trusts: A partial agenda for critical legal scholarship. Journal of Law and Society 14(1): 77-90.

Dorfman, Avihay. 2010. Private ownership. Legal Theory 16(1): 1-35.

Garton, Jonathan. 2015. Moffat's trusts law: Text and materials. 6th ed. Cambridge: Cambridge University Press.

Getzler, Joshua. 2009. Transplantation and mutation in Anglo-American trust law. Theoretical Inquiries in Law 10(2): 356-387.

Grey, T.C. 1980. The disintegration of property. In Property: Nomos XXII, ed. J.R. Pennock and J.W. Chapman. New York: New York University Press.

Hansmann, Henry, and Ugo Mattei. 1998. The functions of trust law: A comparative legal and economic analysis. New York University Law Review 73(2): 434-479.

Harris, J.W. 1975. Variation of trusts. London: Sweet and Maxwell.

Heidegger, Martin. 1962. Being and time. Trans. J. Macquarrie and E. Robinson. Oxford: Blackwell Publishing.

Hohfeld, Wesley N. 1917. Fundamental legal conceptions as applied in judicial reasoning. Yale Law Journal 26(8): 710-770.

Holbraad, Martin. 2011. Can the thing speak: Anthropology, pragmatology, and the conceptual affordances of things. Open Anthropology Cooperative Press Working Paper Series \#7 2. http://opena nthcoop.net/press/http:/openanthcoop.net/press/wp-content/uploads/2011/01/Holbraad-Can-theThing-Speak2.pdf. Accessed 5 October 2018.

Honoré, Antony M. 1961. Ownership. In Oxford essays in jurisprudence, ed. A.G. Guest. Oxford: Clarendon Press.

Jacques, Johanna. 2019. The reproduction of property through the production of personhood: The family trust and the power of things. In Critical trusts law: Reading Roger Cotterrell, ed. N. Piska and H. Gibson. Oxford: Counterpress.

Jaffey, Peter. 2015. Explaining the trust. Law Quarterly Review 131: 377-401. 
Kant, Immanuel. 1996. The metaphysics of morals. Ed. M. Gregor. Cambridge: Cambridge University Press.

Kant, Immanuel. 2012. Groundwork of the metaphysics of morals. Ed. M. Gregor and J. Timmermann. Cambridge: Cambridge University Press.

Kelsen, Hans. 1967. Pure theory of law. Berkeley: University of California Press.

Lametti, David. 2003. The concept of property: Relations through objects of social wealth. University of Toronto Law Journal 53(4): 325-378.

Langbein, John H. 1995. The contractarian basis of the law of trusts. Yale Law Journal 105(3): $625-675$.

Langbein, John H. 2004. Mandatory rules in the law of trusts. Northwestern University Law Review 98(3): 1105-1128.

Langbein, John H. 2010. Burn the Rembrandt? Trust law's limits on the settlor's power to direct investments. Boston University Law Review 90(1): 375-397.

Latour, Bruno. 2005. Reassembling the social: An introduction to actor-network-theory. Oxford: Oxford University Press.

Lau, Martin W. 2011. The economic structure of trusts. Oxford: Oxford University Press.

Lawson, F.H., and Bernard Rudden. 2002. The law of property. 3rd ed. Oxford: Oxford University Press.

Lepaulle, Pierre. 1928. An outsider's view point of the nature of trusts. Cornell Law Review 14: 52-61.

Lepaulle, Pierre. 1933. Trusts and the civil Law. Journal of Comparative Legislation and International Law 15(1): 18-34.

McFarlane, Ben, and R. Stevens. 2010. The nature of equitable property. Journal of Equity 4(1): 1-28.

Maitland, Frederic William. 1911. Trust and corporation. In The collected papers of Frederic William Maitland, vol. 3, ed. H.L.A. Fisher. Cambridge: Cambridge University Press.

Maitland, Frederic William. 1913. Equity: Also, the forms of action at common law: Two courses of lectures. Ed. A. H. Chaytor and W. J. Whittaker. Cambridge: Cambridge University Press.

Matthews, Paul. 2006. The comparative importance of the rule in Saunders v. Vautier. Law Quarterly Review 122: 266-294.

Nolan, Richard. 2015. Appointment, retirement and removal of trustees. In Snell's equity. 33rd ed, ed. J. McGhee. London: Sweet \& Maxwell.

Nozick, Robert. 1974. Anarchy, state, and utopia. New York: Basic Books.

Peñalver, Eduardo M. 2010. The illusory right to abandon. Michigan Law Review 109(2): 191-219.

Penner, James E. 1997. The idea of property in law. Oxford: Oxford University Press.

Penner, James E. 2002. Exemptions. In Breach of trust, ed. P. Birks and A. Pretto. Oxford: Hart Publishing.

Penner, James E. 2009. Value, property, and unjust enrichment: Trusts of traceable proceeds. In Philosophical foundations of the law of unjust enrichment, ed. R. Chambers, C. Mitchell, and James E. Penner. Oxford: Oxford University Press.

Penner, James E. 2014. The (true) nature of a beneficiary's equitable proprietary interest under a trust. Canadian Journal of Law and Jurisprudence 27(2): 473-500.

Pottage, Alain. 2011. Law machines: Scale models, forensic materiality and the making of modern patent law. Social Studies of Science 41(5): 621-643.

Rose, Carol M. 1994. Property \& persuasion: Essays on the history, theory, and rhetoric of ownership. Boulder: Westview Press.

Rudden, Bernard. 1994. Things as thing and things as wealth. Oxford Journal of Legal Studies 14(1): 81-97.

Sanders, Katherine. 2018. 'Beyond human ownership'? Property, power and legal personality for nature in Aotearoa New Zealand. Journal of Environmental Law 30: 207-234.

Scott, Austin W. 1917. The nature of the rights of the 'Cestui Que Trust'. Columbia Law Review 17(4): 269-290.

Shoked, Nadav. 2014. The duty to maintain. Duke Law Journal 64(3): 437-513.

Sitkoff, Robert. 2004. An agency costs theory of trusts law. Cornell Law Review 89(3): 621-684.

Smith, Henry E. 2012. Property as the law of things. Harvard Law Review 125: 1691-1726.

Smith, Lionel D. 2008. Trust and patrimony. Revue générale de droit 38(2): 379-403.

Smith, Lional D. 2017. Massively discretionary trusts. Current Legal Problems 70(1): 17-54.

Spring, Eileen. 1964. The settlement of land in nineteenth-century England. American Journal of Legal History 8: 209-223. 
Tucker, Lynton, Nicholas le Poidevin, and James Brightwell. 2015. Lewin on trusts. 19th ed. London: Sweet \& Maxwell/Thomson Reuters.

Watt, Gary. 2018. Trusts \& equity. 8th ed. Oxford: Oxford University Press.

Worthington, Sarah. 2018. Revolutions in personal property: Redrawing the common law's conceptual map. In Revolution and evolution in private law, ed. Sarah Worthington, A. Robertson, and G. Virgo. Oxford: Hart Publishing.

\section{Cases}

Astor's S.T., Re [1952] Ch 534.

Bradshaw v. University College of Wales [1988] 1 WLR 190.

Chapman's Settlement Trusts (No. 2), Re [1959] 1 WLR 372 (Practice Note relating to Re Rouse's Will Trusts [1958] R 2353).

Goulding v. James [1997] 2 All ER 239.

Quaintance v. Tandan [2012] EWHC 4416 (Ch).

Saunders v. Vautier [1841] 4 Beav 115.

T Choithram International SA v. Pagarani [2001] 1 WLR 1 (PC).

Target Holdings Ltd v. Redferns [1996] AC 421.

Tempest, Re [1865-66] LR 1 Ch App 485.

Vandervell v. Inland Revenue Commissioners [1967] 2 AC 291.

\section{Legislation}

Variation of Trusts Act 1958.

Publisher's Note Springer Nature remains neutral with regard to jurisdictional claims in published maps and institutional affiliations. 